\section{Sebastian Wolf}

Received: 6 March 2006

Accepted: 12 March 2006

Published online: 27 April 2006

C) Springer-Verlag 2006

\section{S. Wolf $(\bowtie)$}

Klinik und Poliklinik für

Augenheilkunde, Inselspital,

Universität Bern,

3010 Bern, Schweiz

e-mail: sebastian.wolf@insel.ch

\title{
Macular pigment measurements: which method should we use?
}

Macular pigment (MP) was investigated as early as 1866 , when Max Schultze concluded that there is a functional connection between the "yellow spot" in the retina and the absorption of blue light. He stated that MP may provide protection against the hazard of short-wavelength visible light. MP consists of the two hydroxycarotenoids lutein $(\mathrm{L})$ and zeaxanthin $(\mathrm{Z})$ and is of is of alimentary origin. Human MP is detectable in the whole retina, but the highest concentrations are found in the fovea [17]. As many antioxidative properties are attributed to the MP, it has been investigated in respect to its role in the pathophysiology of age-related macular degeneration (ARMD). The properties of MP include a high capacity to absorb shortwavelength blue light [19]. The peak of the MP absorbance spectrum is at $460 \mathrm{~nm}$ and works as a broad-band filter for the macula. Two advantages are achieved: (1) the macula's optical accuracy is improved $[11,16]$ and (2) the damaging photooxidative influence on the neurosensory retina is reduced. In the photoreceptor outer segments, the antioxidant effect of $\mathrm{L}$ and $\mathrm{Z}$ is the essential mechanism $[1,22]$. The antioxidant properties enable the carotenoids to neutralize free radicals.

The optical and antioxidant properties of MP, its possible relation to the pathophysiology of ARMD, and the possibility to modify macular pigment optical density (MPOD) by nutritional supplementation have resulted in a growing interest in research on MP. This is reflected by a growing number of papers on MP during recent years.

MPOD can be measured by psychophysical and optical means. These include heterochromatic flicker photometry $[12,24]$ and minimum motion photometry [23], Raman spectrometry $[8,9,14]$, imaging reflectometry $[3,13]$, reflectometry $[4,27]$, and autofluorescence spectrophotometry [12] and imaging [6, 23, 26]. This large number of different methods may explain the inconsistencies between papers on MPOD in patients with various stages of ARMD $[1,2,5,7,10,15,16,18,19,21,24]$. The current issue presents a paper in which Trieschmann et al. [25] present MPOD measurements using autofluorescence images. They compare a method [27] based on pioneering work from Delori et al. [12] using autofluorescence images obtained at two wavelengths ( $488 \mathrm{~nm}$ and $514 \mathrm{~nm}$ ) by means of a method presented by the same group previously $[23,26]$ using autofluorescence images obtained at one wavelength $(488 \mathrm{~nm})$. They describe in great detail the theory of MPOD measurements using autofluorescence imaging, repeating previous work [12]. In their manuscript they conclude that the one-wavelength method is adequate for visualizing the MP but not for determining MPOD, whereas the two-wavelength method allows for accurate determination of 
MPOD. These conclusions are mainly based on the theoretical considerations presented in the methods section. However, the actual measurements presented in the paper do not permit these conclusions. There is no evidence that one method is better than the other, since no comparison with an independent measure of MPOD based on a more established technique such as psychophysics is presented in the manuscript. However, recently a comparison between the two-wavelength method using autofluorescence imaging (AF) and the heterochromatic flicker photometry (HFP) technique has been published [20]. In this paper no correlation between the two methods was presented. However, the large difference in the coefficient of variation for repeated measurement between the two methods $(16.6 \%$ for HFP vs 3.3\% for AF) suggests that the two-wavelength AF method is more precise than the HFP method for determination of MPOD [20].

Recent work suggests that the distribution of MP could be more important than central MPOD $[6,18$, 23]. Therefore, future studies on MP should use a method allowing measurement not only of MPOD in the foveal center but also of MP distribution. Since the determination of MP distribution with psychophysical methods is difficult and very time consuming, MPOD measurement by imaging methods appears to be more suitable for clinical studies. The theoretical considerations presented in the paper by Trieschmann et al. [25] suggest that we should abandon the one-wavelength AF method and use only the two-wavelength method for future studies.

\section{References}

1. Beatty S, Boulton M, Henson D, Koh HH, Murray IJ (1999) Macular pigment and age related macular degeneration. Br J Ophthalmol 83(7): 867-877

2. Beatty S, Murray IJ, Henson DB, Carden D, Koh H-H, Boulton ME (2001) Macular pigment and risk for age-related macular degeneration in subjects from a northern european population. Invest Ophthalmol Vis Sci 42:439-446

3. Berendschot TT, Goldbohm RA, Klopping WA, van de Kraats J, van Norel J, van Norren D (2000) Influence of lutein supplementation on macular pigment, assessed with two objective techniques. Invest Ophthalmol Vis Sci 41(11): 3322-3326

4. Berendschot TT, van Norren D (2004) Objective determination of the macular pigment optical density using fundus reflectance spectroscopy. Arch Biochem Biophys 430(2):149-155

5. Berendschot TT, van Norren D (2005) On the age dependency of the macular pigment optical density. Exp Eye Res 81(5):602-609

6. Berendschot TT, van Norren D (2006) Macular pigment shows ringlike structures. Invest Ophthalmol Vis Sci 47(2):709-714
7. Berendschot TT, Willemse-Assink JJ, Bastiaanse M, de Jong PT, van Norren D (2002) Macular pigment and melanin in age-related maculopathy in a general population. Invest Ophthalmol Vis Sci 43(6):1928-1932

8. Bernstein PS, Yoshida MD, Katz NB, McClane RW, Gellermann W (1998) Raman detection of macular carotenoid pigments in intact human retina. Invest Ophthalmol Vis Sci 39:2003-2011

9. Bernstein PS, Zhao DY, Wintch SW, Ermakov IV, McClane RW, Gellermann W (2002) Resonance Raman measurement of macular carotenoids in normal subjects and in agerelated macular degeneration patients. Ophthalmology 109(10):1780-1787

10. Bone RA, Landrum JT, Mayne ST, Gomez CM, Tibor SE, Twaroska EE (2001) Macular pigment in donor eyes with and without AMD: a case-control study. Invest Ophthalmol Vis Sci 42 (1):235-240

11. Dagnelie G, Zorge IS, McDonald TM (2000) Lutein improves visual function in some patients with retina degeneration: a pilot study via the internet. Optometry 71:147-164

12. Delori FC, Goger DG, Hammond BR, Snodderly DM, Burns SA (2001) Macular pigment density measured by autofluorescence spectrometry: comparison with reflectometry and heterochromatic flicker photometry. J Opt Soc Am 18:1212-1230

13. Elsner AE, Burns SA, Huges GW, Webb RH (1992) Quantitative reflectometry with a scanning laser ophthalmoscope. Appl Opt 31(19):3697-3710
14. Ermakov I, Ermakova M, Gellermann W, Bernstein PS (2004) Macular pigment Raman detector for clinical applications. J Biomed Opt 9(1): 139-148

15. Gellermann W, Ermakov IV, Ermakova MR, McClane RW, Zhao DY,

Bernstein PS (2002) In vivo resonant Raman measurement of macular carotenoid pigments in the young and the aging human retina. J Opt Soc Am A Opt Image Sci Vis 19(6):1172-1186

16. Hammond BR Jr, Wooten BR, Snodderly DM (1997) Density of the human crystalline lens is related to the macular pigment carotenoids, lutein and zeaxanthin. Optom Vis Sci 74 (7):499-504

17. Handelman GJ, Dratz EA, Reay CC, van Kuijk JG (1988) Carotenoids in the human macula and whole retina. Invest Ophthalmol Vis Sci 29:850-855

18. Jahn C, Wustemeyer H, Brinkmann C, Trautmann S, Mossner A, Wolf S (2005) Macular pigment density in age-related maculopathy. Graefes Arch Clin Exp Ophthalmol 243(3):222-227

19. Landrum JT, Bone RA (2001) Lutein, zeaxanthin, and the macular pigment. Arch Biochem Biophys 385(1):28-40

20. Liew S, Gilbert C, Spector T, Mellerio J, Marshall J, van Kuijk F, Beatty S, Fitzke F, Hammond C (2005) Heritability of macular pigment: a twin study. Invest Ophthalmol 46(12):4430-4436 
21. Pauleikhoff D, van Kuijk FJ, Bird AC (2001) Macular pigment and age-related macular degeneration. Ophthalmologe 98(6):511-519

22. Rapp LM, Maple SS, Choi JH (2000) Lutein and zeaxanthin concentrations in rod outer segment membranes from perifoveal and peripheral human retina. Invest Ophthalmol Vis Sci 41: 1200-1209
23. Robson AG, Moreland JD, Pauleikhoff D, Morrissey T, Holder GE, Fitzke FW, Bird AC, van Kuijk FJ (2003) Macular pigment density and distribution: comparison of fundus autofluorescence with minimum motion photometry. Vis Res 43(16):1765-1775

24. Snodderly DM, Mares JA, Wooten BR, Oxton L, Gruber M, Ficek T, Group CMPS (2004) Macular pigment measurement by heterochromatic flicker photometry in older subjects: the carotedoids and age-related eye disease study. Invest Ophthalmol 45(2): 531-538

25. Trieschmann M, Heimes B, Hense H, Pauleikhoff D (2006) Macular pigment optical density measurement in autofluorescence imaging: Comparison of one and two wavelengths method. Graefes Arch Clin Exp Ophthalmol
26. Trieschmann M, Spital G, Lommatzsch A, van Kuijk E, Fitzke F, Bird AC, Pauleikhoff D (2003) Macular pigment: quantitative analysis on autofluorescence images. Graefes Arch Clin Exp Ophthalmol 241(12):1006-1012

27. Wüstemeyer H, Jahn C, Nestler A, Barth T, Wolf S (2002) A new instrument for the quantification of macular pigment density: first results in patients with AMD and healthy subjects.

Graefes Arch Clin Exp Ophthalmol 240 (8):666-671 